\title{
Motus Dei (The Move of God): A Theology and Missiology for a Moving World
}

\author{
Dr. Sam George \\ Global Diaspora Institute, Wheaton College \\ Illinois, United States of America \\ Prof. Dr. Godfrey \\ Harold Cape Town Baptist Seminary \\ Research Associate: Stellenbosch University, South Africa \\ Email: godfrey@ctbs.org.za
}

\begin{abstract}
Doi: https://doi.org/10.46222/10216

This article engages Christian doctrines to introduce and develop the concept of Motus Dei by arguing that God of the Bible is continually on the move and as one who beckons his followers to come alongside to see what God is doing in the world. Thus, the mission is about moving with God to see all things made new as we harmonize our wandering steps to be in sync with a moving God. The mission is following God, moving in, and catching up with God in many different cultural and geographical spaces all over the world, and to grow in our appreciation of God's work in, through and around us as we move. The authors venture into the domains of theology (proper), anthropology, soteriology, pneumatology, and eschatology, as they attempt to construct a new theology and missiology for a world in motion. The work draws from the rich resources of the Christian faith to try to comprehend God and His work in a world of unprecedented human mobility and consequent societal and global transformations brought about by what is now considered an 'age of migration'.
\end{abstract}

Keywords: God, mission, movement, theology, diaspora, migration.

\section{Introduction}

God is on the move. God is moving in the lives of men and women across the street and around the world. The message of the Kingdom of God is going forth remarkably these days, and God's reign is advancing in unexpected ways. God is powerfully moving among the people who are on the move. The migrants, displaced peoples, and diaspora communities are at the forefront of God's mission in the world today. The migration is one of the mega-themes of the Biblical narratives. The trajectory of the salvation history and church worldwide has been reshaped repeatedly by the people on the move.

\section{Moving God: Creation and Trinity}

God of the Bible is a missionary God (Stott, 2006: 71-74) because God is always on the move, and God is on the move because God is a living being. The divine attributes of omnipresence, immutability and impassibility, should not lead us in the direction of viewing God as rigid, static, immovable and stationary. God cannot be confined in space or time, yet sovereign over spatial and chronological realms. After closely examining the history of Israel given in the sermon of the first Christian martyr Stephen in the book of Acts, Stott (1994: 132) concluded that "God of the Old Testament was the living God, a God on the move and on the march, who was always calling his people out to fresh adventures, and always accompanying and directing them as they went". This is demonstrated in the Exodus narrative of the Israelites leaving Egypt. 
It is to be noted that that the creation account describes God as moving; we read, "the Spirit (Ruach) of God was hovering over the waters" (Genesis 1:2) where we observe God's movement over the earth that is without form, empty and dark. Even before God spoke creation commands in Genesis 1:3 and thereafter, we see God moving over the earth. Before the illuminating, life-creating, and order-making creative work of God, we see a moving God. Some translations use words such as blowing, soaring, sweeping over, or moving in place of hovering and could be compared with the word mentioned in Deuteronomy 32:10, which renders imagery of an eagle hovering over its nest. The Hebrew noun for God in Genesis 1:1 is plural which establishes the Trinitarian foundations from the very beginning, and Pentecostal theologians (Keener, 2017; Ma and Ma, 2011; Young, 2014) all affirm the role of the Spirit in the Creation using Genesis 1:2. One may argue that the divine utterances of creation resulted from divine movement and in response to it.

Moreover, the Creation account records the earth as being formless and as a void (Genesis 1:2). Thus, God "separated" and "gathered" on days 1 to 3 to establish a form and God's "making" and "filling" in days 4 to 6 to remove the emptiness. Likewise, scattering and gathering could be seen as mega-themes of divine action throughout to establish God's reign in the created order. The Creation Mandate to be "Be fruitful and multiply, and fill the earth and subdue it." (Genesis 1: 28) charges human beings to be stewards over the creation on God's behalf and its scope covers the whole earth, requiring humanity to move from place to place. Unlike the Creator, who is not confined by space or time, and one who is sovereign, God is found moving about. The creatures have to navigate beyond their spatial subjectivities to establish the divine reign on the earth. This mandate encompasses the human destiny to be a communal being to inhabit and shape social life and the natural world. The Fall is portrayed as alienation and expulsion from the Garden, a form of forced displacement and sets the stage for eventual redemption, which could be conceived as moving back to a state of restored communion and proximity to the divine being, thus requiring soteriology to be articulated afresh in locational and relational terms.

God moves within Godself and outside of Godself. McGrath (2011:325) states that the Trinitarian nomenclature of the three persons of the Triune Godhead as co-indwelling, coinhering, and mutual interpenetration "allows the individuality of the person to be maintained while each person shares in the life of the other two." God moves because God is Trinity since both monotheistic and tri-theistic ideation will make the Godhead motionless while the polytheistic notion of god makes them territorial. The conceptualization of Trinitarian relationality and the dance of perichōrēsis requires kinematic imagination as it cannot be grasped solely in a static state. The Trinity provides the basis of ontological foundations for understanding human personhood and interpersonal relations (Zizioulas, 1985, Volf, 1998).

The relationality of Trinity allows Godself to move toward each other and together move into the created order and the entire cosmos. Laguna (1983:353) argues that "God goes forth from God, God creates the world, God suffices its history and dwells within it, redeeming the world from within". Such a model of Trinitarian God has many implications on theological anthropology, and for this, such intrinsic sociality of human beings requires mobility, without which the creature is not fully alive or social. Another important manner as to how humans relate is through language and being in communication with other human beings, which is closely tied to the idea of being in motion. The etymology of the word migrate is instructive and related to commute, commune, communication and other words. Thus, Vanhoozer (1997:177) states "Human are like God in their capacity to go out of themselves and enter into personal relations through communicative agency". The history of innovations in transportation, trade, and communication have a symbiotic relationship with the history of human migrations. 
In contrast to a living and moving God, idols cannot move about and need to be carried from place to place (Jeremiah 10:5). Idols and territorial spirits are bound within geographical confines and keep devotees chained to a locale. Calvin (1964:116-117), therefore, expounded the second commandment that representing God in images was forbidden because people are bound by physical surroundings when they create an image of a deity, they are distracted from God's true spiritual being, and to some degree, the deity is conceived in some corporeal way. In developing a theology of idolatry, Baele (2008:44-49) asserts that we become what we worship as without mouths, eyes, ears, hands or feet, based on Psalm 115:8, "those who make them (idols) will become like them". We, therefore, resemble what we revere, either for ruin or restoration. In other words, idolatry makes us lifeless and fastened to geography like a dead person.

A static view of God turns the divine being and created humanity as lifeless, sterile and immobile. The insular nature of idolatrous societies stems from their provincialism, making their religions less transportable and missionary. The parochial tendencies restrict the territorial dominion of evil and demonic spirits as they are not omnipresent or omniscient like God of the Bible. The beliefs of ancestral worship and mediation to guardian spirits point to territorial bondage and ethnic elitism while people remain imprisoned to a locality. These gods, spirits and ancestors reside in a particular object or territory and protect people who reside within its vicinity. Their powers do not extend beyond those areas, and when people travel to distant places, they are no longer under the protection of their gods and expected to change their allegiance to a stronger God of the new region and serve him. In contrast to tribal spirit deities, Hiebert (2008:117) therefore argues, "Jehovah declared himself not to be a territorial god but the God of the universe".

When the physicality of Solomon's Temple in Jerusalem occupied a more overbearing place for Israelites, and considerable superficiality, corruption, and ritualism took over, God allowed it to be destroyed by invading armies, resulting in the Exile of the Israelites. The Tabernacle was more archetypal of a moving God than a sedentary God of the Jerusalem Temple. At the transfiguration of Jesus, the response of the disciples was to "Let us put up three shelters" (Mark 9:5) as they wanted to erect tents to memorialize or establish a shrine at that place. The divine corrective to disciples affirmed the Sonship of Jesus and called them to obey him. Likewise, Jesus resolved the dilemma faced by the Samaritan women about the true place of worship between Mount Gerizim for Samaritans and Jerusalem for Jews by exhorting her that it is neither here nor there but "true worshipers will worship in truth and spirit." (John 4:24). The place has been deemed inconsequential, and Jesus broke through the human tendency to domesticate God and bind the infinite, boundless Spirit within cultural and geographical particularity.

Japanese theologian Koyama (1985:88) compared Mount Fuji, the cosmological centre of the world, according to the Japanese imperial ideology with Mount Sinai, the place of divine epiphany and where the Decalogue was given to the Israelites. The image of the mobile God did not concede Mount Sinai to become a place of worship and their imagination of God to be bound to a place. Instead, God himself "symbolizes the centre of salvation. The centre symbolism travels with the people". He further contends that centrality, whether an individual, a race, a nation, an institution, or an empire, is always open to abuse and exploitation by a destructive ideology.

\section{Created to Move: Being and Fall}

A doctrine of humanity needs to be articulated in motile terms to understand our innate propensity toward peripatetic wanderings. Here, the authors contend that human movability is a characteristic feature since we are created "in the likeness of God" (Genesis 1:26), similar to the notions of human rationality, relationality, dignity, identity, solidarity, freedom, worth and 
other dominant interpretations of the image of God (Imago Dei) in the classical theological texts. We are created to move because we bear the image of a moving God, and it is high time to reimagine theological anthropology and mission theology kinesiologically.

'I move, therefore I am' (moveo ergo sum) is more pertinent in the age of migration than Descartes' dictum. Augustine (1963) spoke of human life as ever on the move: "You have made us toward yourself, and our hearts are restless until they rest in you". Walls (2011) argued that the history of humanity was "determined by the movements of peoples", and Groody (2012:409-424) claimed that the theme of migration is intrinsic to our biological and spiritual genes.

We are created to move about, and only when we move are we fully alive and exhibit our likeness to our Creator. The inability to move denies personhood and utterly dehumanize the person. Magloire (1991:128) postulates that being created in the image of God is not a state or condition but a movement with a goal. Such a directional teleology can aid the development of a more nuanced construal of the doctrine of the Fall as alienation or falling away using Biblical narratives of Expulsion from the Garden, the Call of Abraham, the Exodus, the Exile and other texts. This will help to reconceive the soteriological task as a moving experience "passing over from death to life" and "out of the Kingdom of darkness into his marvellous light" (1 Peter 2:9; Acts 26:17). The contemporary urban nomadism and migration across national borders only prove that we are truly homo mobilis.

In his Areopagus sermon, Apostle Paul quoted Cretan poet and philosopher Epimenides of the $7^{\text {th }}$ Century BCE "In him, we live and move and have our being" (Acts 17:28) and used it talk about a God who made the world and everything in it, in contrast to pantheistic Stoicism. He went on to confront the idolatry of the Athenians, introduce Jesus and calls his listeners to repentance. At the heart of this comparison is the belief that human existence and our very being are intricately linked to our capacity for motion, and all of it is derived from the divine being who is not a mere lifeless and immotile idol crafted by human hands. We move in response to God, who is on the move incessantly. This moving nature is not only a sign of being alive but lies at the very core of our identity. This also presents that the created human being is in total and continually dependent on the Creator for its existence, sustenance, abilities and activities. All living creatures, especially human beings, are brought to life by the divine breath (Genesis 2:7). In the second of the four speeches Elihu makes to Job, he states, "If he [God] would take back his spirit to himself, and gather to himself his breath, all flesh would perish together, and man would return to dust." (Job 34:14-15). Paul believed that "he himself gives all men life and breath and everything else." (Acts 17:25). Jesus told his disciples that the "Son can do nothing of his own accord, but only what he sees the Father doing" (John 5:19) and "apart from me you can do nothing" (John 15:5).

Later in the same sermon, Paul used a Cilician poet Aratus (c 315-240 BCE) from his writings called Phaenomena - "We are God's offspring" (Acts 17:28b) and finds a common anthropological and theological ground with the audience using pagan literature. Paul suggests that the unknown god of the Athenians was the God of Jesus Christ and finds a mutually tenable platform to engage his heathen listeners evangelistically without alienating them. He was more inclusive and tried to identify with his interlocutors without creating a 'us versus them' division. Earlier, he had claimed that from one man, God had made every nation inhabit the whole Earth and thus argued that the whole of humanity has a common ancestry. Yong (2014:129-131) used this passage to renew his vision for pneumatological missiology of the Spirit for a pluralistic context of the $21^{\text {st }}$ century. As migration brings different people and cultures closer together who hold different belief systems, theological anthropology in terms of mobile, familial kinship and mutuality of human diversity without compromising the core convictions is required not to undermine a credible witness of the gospel. 
In the Athenian discourse, the Apostle Paul also claimed the sovereignty of God over human dispersion, saying God "determined the times set for them and the exact places where they should live." (Acts 17:26). Beyond the economic, sociological, legal, and political dimensions of human migration, we see a divine origin at work as people change their domicile across borders. Paul explicates the reason why God moves people and underscores the spiritual consequences of the migration. God moves people so that they would seek after him. Though God is not distant from them, the migrants come near to God after moving to a new place. Displacement makes people seek after God in new ways by testing the validity of their past beliefs in new contexts while being open to other alternatives and spiritual experiences. They compare and contrast the worlds they are exposed to while striving to seek the ultimate truth claim. No wonder migration, according to Smith (1978:1181), is considered as "a theologizing experience".

Christians are more likely to travel beyond their birthplace since they are not bound to any locale, and their peripatetic encounter with foreign cultures and languages leads to new endeavours in adapting the tenets of their faith and practices into new contexts. Some opine that 'if you are a Christian, you will travel, and if you travel, you will become a Christian.' This phenomenon was observed with the Indian indentured labourers arriving in South Africa during 1860-1940. In 1940, there was no more than $2 \%$ of the Indian who were Christians in South Africa. However, by 1990 Indian Christians made up 25\% of the Indian population in South Africa (Harold, 2019a: 57-68). On the contrary, Hinduism is considered a rooted religion because of its prohibition to traverse large expanses of water in its scriptures, dietary restrictions, pollution, purification rituals upon return, demotion in the social hierarchy, and the fear of dying in a foreign land. Hindus are expected to live and die in a place close to where they were born, and most remain bound mainly within a particular place, specific land and culture (George, 2000).

George (2019:69-88) further articulates his point that their destiny is determined by their place of birth, both within the confines of geography and caste hierarchy. The only way to escape the Karmic fatalism is to migrate out of the territorial boundaries of such a god and change allegiance to a more benevolent God. Likewise, Islam is also a rooted religion on account of its pilgrimage; prayers uttered facing a particular direction and untranslatable scriptures. Sanneh (2009:262) succinctly juxtaposed both faiths by alleging "Muslim hijrah bequeathed a legacy of geographical and linguistic orthodoxy while the Christian Pentecost created the reverse, an abandonment of the idea of divine territoriality".

\section{Moving to Save: Incarnation and Salvation}

The incarnation means to take on, become, or enter into flesh. It refers to the Christian doctrine that the pre-existent Son of God became a man in Jesus. The birth of Jesus can be understood as a move of God into an alien world to become a human being within a particular sociocultural and historical setting, yet without losing his divinity (Erickson, 2013, McGrath, 2011). Thus, by incarnation, God in the person of Jesus crosses the divide between the divine self and the created order. The New Testament does not use static or metaphysical concepts to explain the mystery of the incarnation. Rather it is seen in terms of a dynamic movement. The Johannine gospel describes the incarnation as "Word become flesh and made his dwelling among us." (John 1:14), where God is portrayed as moving into our neighbourhood or pitching his tent next door. The imagery is closely linked to the Old Testament idea of the Tent of Meeting, which was filled by the glory of God (Exodus 40:34-35) and portable sanctuary of God during the wilderness period, which later becomes the model for the Temple in Jerusalem (Exodus 25). God was moving with his people, and a visible presence of God was in the form of a cloud by day and fire by night that assured the people on their arduous journey to their Promised Land. 
Likewise, the apostle Paul speaks of the incarnation of Jesus, the second person of the Trinity in terms of emptying (kenosis) of himself in becoming a human being and finally, his exaltation in the resurrection (Philippians 2: 6-11). This hymn depicted incarnation as descent and lowering to become nothing. The mystery of the incarnation of Jesus, who did not give up his deity but laid aside his glory, being fully man and fully God, was explained using kinetic terms such as being poured out, lowered, exalted, highest place, above all, etc. Such a Christology starts from above, descends to the level of a human being, and ascends again to the divine plane. On the contrary, in the Acts of the Apostles, we have a Christology from below, starting with the human life of Jesus Christ and the ascension and angelic assurance to the disciples about the second coming of Jesus. (Acts 1:10 and 11). These verses are loaded with directional and motional words such as lookup, sky, stood beside, here, above, going, taken from, come back, go into, etc. The New Testament accounts focused on the functional aspect of Christ, his life, teaching and redemptive activities. At the same time, in later centuries, theologians took a metaphysical approach to understand his being as having two natures (divine and human) united in one person.

The Aristotelian concept of "unmoved Mover" had a significant influence on Christian metaphysics and the notion of the attributes of God's divinity, such as God's immutability and impassibility (Harold, 2013). However, Moltmann (2015:11) believes that the Biblical experience of God would more likely correspond to a "self-moved Mover" because "God moves out of Godself and loves the being God has created". The belief that what is divine is not subjected to change over time or change brought about by an external force. The divine character of immutability does not deprive a divine being of its vitality, while the impassibility and immovability make God to be dead rather than a living and active being to the movement of his people (Harold, 2013:173). In "coming down to deliver" his people, we see God moved by compassion after "seeing the affliction of my people and have heard their cry" (Exodus 3:8). God descends for his people's sake, liberating them from their bondage and suffering in Egypt and leading them to the Promised Land by going before them. The view of these as anthropomorphism does not take the human subject's likeness to God seriously, and viewing God as immovable and incapable of love or suffering makes Godhead less divine.

Soteriology cannot only be conceived as acquittal, expiation, justification, atonement and redemption from sin and death as commonly done in western theological writings but also in relational, religious and motile terms such as reversal of estrangement, alienation, ostracization and contamination using conceptual ideation like brought near, reconciliation, purification and restoration. Generally, the effect of the Fall is traced as inherited guilt or corruption of humanity for which salvation is presented as a gift of grace through Christ's death. The finished work of Jesus on the cross offers substitutionary atonement and wholeness and fullness through soul cleansing, adoption into the family of God, and restoration of a broken relationship. In shame and honour-based communitarian cultures require a more holistic and multidimensional stance of Christian salvation (Wu, 2015).

The ultimate salvation for Christian is their eschatological vision of the future, which helps them pivot their present predicaments in light of eternity and live with their eyes set on the Saviour and eternal life. Ott claims (2010:90) that the eschatological kingdom is the ultimate goal of all missionary work and mission is all about witness to the reign of God which has come in Jesus Christ, and one yet coming.

Christians move, whether in the form of missionaries or migrants, across the cultural and geographical boundaries and in the process of getting uprooted and transplantation, they become strangely aware of the moving of God in their lives and the new locations they find themselves in. Many become Christians after moving to new places, whether for economic opportunities, educational prospects, or forcibly displaced because of famine, wars or persecution. Faith in a moving God becomes an indispensable resource for people on the 
move, and they become natural evangelists and cultural translators over time, exerting missional influence on places of origin, sojourn, and settlement. During their earthly peregrine life, the pilgrim people of God have no abiding city on earth but look forward to the city with a foundation whose make and builder is God (Hebrew 11:10). They have no fixed abode on earth; earthly home is a paroikia (dwell beside or among), a temporary residence with eyes fixed on their eternal abode (Multmann, 1993).

The eschatological hope of believers propels them to live each day faithfully with a divine sense of a grander purpose for their transitory lives to participate in the mission of God. Thus, the displaced immigrants serve a missionary function just as the functional missionaries are culturally displaced migrants.

\section{Mission in Motion: Migration and Movements}

At its core, the Christian faith is a diasporic missionary faith. If it remains captive to a culture, people or geography, it will turn into a religion like any other and be deprived of its innate dynamism. Much of the Bible is written in diasporic contexts. A common thread that runs throughout its pages is the select people and nation that God displaced in the different epochs of history to advance His reign in the world. The salvation history is framed within migratory wanderings, and much of Christian expansion and transformation over the last two millenniums have ensued in diverse diasporic contexts. The expansion of Christianity has occurred along the trajectories of human dispersions as they become a conduit for the reinvigoration and cultural diffusion of the gospel from one group of people to another group of people. It has now reached every geopolitical entity in the world while becoming the most global, dispersed, and diverse faith in the world.

In developing a radically new Christian theological framework by reversing the order of theological formulation for the increasingly charismatic form of spirituality, diversity of global Christianity, and its missionary character since its beginning, Yong (2014:2) concluded that "Christianity was a transportable religion. Arguably its mobility lay in its capacity to accommodate itself to many different cultures, languages and people groups". It is the mobility of its adherents that took early Christians to the fringes of the Roman Empire, on account of religious persecution and the socio-economic conditions stemming from Pax Romana that spread Christianity throughout the Mediterranean rim and beyond. About the early history of Christianity, Harnack (1904:463) has noted that "the apostles, as well as many of the prophets, travelled unceasingly in the interest of their mission. Paul...his fellow workers and companions were also continually on the move". Christians are mobile people since they get unhinged from geographical, socio-cultural, fiscal and political bondages of a particular locality. The Anonymous Epistle to Diognetus written in 124CE, cited in Sanneh (1990:1-22) asserts that "The difference between Christians and the rest of mankind is not a matter of language, customs, or nationality. For them, any country is a motherland, and any motherland is a foreign country".

The nature of the Christian faith is that its centre lies outside the circle, which continually pivots itself with new people and new centres. In establishing the nature of the church for the reign of God, Gutierrez (1973:260) contended, "Its [church] existence is not 'for itself' but rather 'for others." Its centre is outside itself; it is in the work of Christ and his Spirit. Mission, thus, it is pivoting the message of the gospel of the risen Jesus outside the walls of the church with an eschatological orientation and pneumatological empowerment. No wonder the ancient Greek Mathematician came out with the principle of a lever and fulcrum that is widely used in common gadgets and engineering applications, who claimed that he could 'move the Earth, if he had a place to stand outside of it and a lever long enough.' Christian faith is translatable and continually engaged in tweaking its scriptural interpretation and practices. Sanneh (1990) 
claimed that vernacular translation of the Bible has played a central catalytic role in the spread of the Christian faith.

Therefore, the Christian message can be expressed in any language and interpreted into any culture. Christian faith can be at home in any culture, and it cannot be bound within any culture or geography for its very nature makes it diffuse across cultural lines. The translatability factor helped the spread of Christianity to new cultures across many regions of Africa, Asia, and Latin America in the last few centuries. Consequently, it can be argued that it is the mobility that results in its translatability as displacement creates the need to bridge the linguistic divide. Moreover, it is evident from the great European migration and the modern missionary movement, which took people who had richly benefited from the translation of the scripture to become champions for the cause of Bible translation into vernacular languages in places they went to.

Several new theologies of the mission have recently emerged namely: journey, sojourner, pilgrim, hospitality, migration, alien, and exile as major theological motifs to understand the contemporary mission for a world that is in perpetual motion (Bartholomew \& Hughes, 2004). Although some have maintained that "journey" does not offer a helpful analytical concept for describing Paul's missionary praxis since he lived and worked in Corinth and Ephesus for two years each. However, it can be argued Paul's travels, ministry, and writings have emerged as a result of he being a product of the Jewish diaspora, his work began with diasporic settlers, and his distinctive conceptualization of the gospel from a diasporic vantage point, liberated it beyond Jewish captivity into the broader Gentile world (Barclay, 2016).

An apt metaphor for doing mission in the age of migration is 'shooting a moving target'. Our theologies and strategies for mission engagement have to be carefully scrutinized and completely reinvented in the context of global migration. Many Unreached People Groups are no longer confined within a window or a geographical region but have relocated to other nations (De Korte and Onnekink, 2020) As in archery, strategies to shoot a fixed target and moving target are poles apart, and archers are to be trained not to shoot where the target is at present, but rather where it will likely be when the arrow reaches that place. This requires anticipating where the target is going, creative and quick thinking, mastery over equipment, taking into account the environment, and being prepared for high failure rates.

A major development at the turn of the twenty-first century is the move (or shift) of "the centre of gravity of Christianity" in the world from the Global North to the Global South, first noted by Walls (2002:45-47). Subsequently, many have examined it at length only to confirm the trend and its far-reaching repercussions. Christianity has a universal Saviour and is now more global, geographically dispersed, and more diverse than it has ever been in its entire history, closer to "the full stature of Christ" (Ephesians 4:13). This 'Ephesian Moment' holds tremendous potential for a much-increased momentum in mission while it also poses many new challenges. Christians from other cultures and regions of the world can enrich our understanding of the faith, remedy our mistakes, enlarge our parochial perspectives, and help us gain a fuller perspective of God's moving work among all peoples of the world.

Undoubtedly, one of the major theological innovations of the last century is the notion of the Missio Dei, understanding mission as God's mission (Bosch, 200: 390; Harold, 2019b). Based on the Barthian conceptualization, mission was no more perceived as an activity of the church but an attribute of God derived from the very nature of God and framed within the context of the doctrine of the Trinity, not based on ecclesiology or soteriology. The mission is seen as a movement from God to the world, and the church is viewed as an instrument of that mission. Such movement is not limited to a particular incident or age, but God is continually moving toward the world and his creation to recreate it and establish his reign. The development of 
missional ecclesiology further emphasized the sending nature of God and the church (Harold, 2019b).

However, it fortified the critical role of the sending bodies, the socio-cultural and economic disparity between senders and receivers, reproduction of sending institutional cultures, unhealthy dependencies, lopsided power structure, and a form of neo-colonialism. The sending model is incongruous for reimagining the work of God in a postcolonial, post-Western, post-Enlightenment, post-Christendom, and post-mission era (Yong, 2019). The contemporary mission praxis is from everywhere to everywhere, multilateral, multidirectional, sending as well as receiving, and polycentric meshed network requiring it to be conceived as polycentrifugal and polycentripetal flow (Yeh, 2016). A multidirectional scattering and gathering are helpful motifs to understand the contemporary moving of God in the world.

\section{Conclusion}

Christianity is a missionary faith par excellence since it is a faith that was born to travel. In fact, the mobility of its adherents and the moving nature of God is what makes the Christian faith a transportable and translatable faith as it continually transcends borders of all kinds over time. The movement of people is of utmost significance to the Christian faith as displaced people have reconfigured the contours of its growth and expansion throughout its history. Since its inception, Christianity has diffused across cultural and geographical lines repeatedly, and many different people in varied places have been the chief representative of Christianity. The Christian faith cannot be bound to a location or domesticated by any people because its nature is to break free of the prisons we enshrine it in. It is constrained to continually move from one place to another because it is a quintessential missionary, translatable and mobile faith. Seeing God as a moving person and his ongoing work as a result of the moving of God is a helpful way to develop a theology and missiology for a moving world. A fresh formulation using Motus Dei can help in this regard, and it is consistent with the biblical, historical and ongoing work of God in the world.

\section{References}

Augustine. (1963). Confessions, translated by Rex Warner. New York: Mentor.

Bartholomew, C. \& Hughes, F. (2004). Exploration in a Christian Theology of Pilgrimage, London: Routledge

Barclay, J. M.G. (2016). Pauline Churches and Diaspora Jews, Grand Rapids: WB Eerdmans.

Beale, G.K. (2008). We become what we Worship: A Biblical Theology of Idolatry, Carol Stream: InterVarsity Press.

Bosch, D. (2001). Transforming Mission: Paradigm Shifts in Theology of Mission, Maryknoll, NY: Orbis Books.

De Korte, Hannah. and Onnekink, David. (2020)._ "Maps Matter. The 10/40 Window and Missionary Geography". Exchange, Vol. 49,2 pgs 110-144.

https://brill.com/view/journals/exch/49/2/article-p110_3.xml?language=en. Accessed on 29 May 2021.

Calvin, J. (1964). Commentaries on the Last Four Books of Moses, Grand Rapids: Eerdmans,

Elwell, W. A. (1984). Evangelical Dictionary of Theology, Grand Rapids: Baker Books. 
Escobar, SI. (2003). The New Global Mission: The Gospel from Everywhere to Everyone, Downers Grove, IL: IVP Academic.

Flett, J. (2010). The Witness of God: Missio Dei, Karl Barth and the Nature of Christian Community, Grand Rapids: WB Eerdmans.

Flett, J. \& Congdon, D. Eds. (2017). Converting Witness: The Future of the Christian Mission in New Millennium, Lanham: Lexington Books.

George, S. (2019). "Crossing Kala Pani: Overcoming Religious Barriers to Migration" in Diaspora Christianities: Global Scattering and Gathering of South Asian Christians, ed. Sam George. Minneapolis: Fortress Press.

George, Sam. (2020). "Diaspora Mission and North American Muslims" in Evangelical Mission Quarterly, (Vol. 56,3), July-September.

Gittins, A. (2002). Ministry at the Margins: Strategy and Spirituality for Mission, Maryknoll: Orbis Books.

Groody, D. (2012). "Homebound: A Theology of Migration" Journal of Catholic Social Thought (Vol. 9,2) pgs 409-424.

Gutierrez, G. (1973). Theology of Liberation, Maryknoll: Orbis Books.

Hanciles, J. (2008). Beyond Christendom: Globalization, African Migration, and the Transformation of the West, Maryknoll: Orbis Books.

Harnack, A. (1904). The Expansion of Christianity in the First Three Centuries, London: Williams and Norgate.

Harold, G. (2013). An Evangelical Discourse on God Response to Suffering: A Critical Assessment of Gregory Boyd's Open Theism. Unpublished PhD: University of Western Cape.

Harold, G. (2019a). From Cane Cutters to Church Planters: The Story of The Indian Church in South Africa In: Sam George (ed) Diaspora Christianities: Global Scattering and Gathering of South Asian Christians, Minneapolis: Fortress Press.

Harold, G. (2019b). "An Evangelical Understanding of The Missio Dei as Inclusion of Social Justice: A Critical Theological Reflection”. Pharos Journal of Theology, Volume 100 http//www.pharosjot.com. Accessed 25 May 2021.

Hiebert, P.G. (2008). Transforming Worldviews: An Anthropological Understanding of How People Change. Grand Rapids: Baker Academics.

Jenkins, P. (2002). The Next Christendom: The Coming of Global Christianity, New York: Oxford University Press.

Keener, C. (2017). Spirit Hermeneutics: Reading Scripture in Light of Pentecost, Grand Rapids: WB Eerdmans.

Koyama, K. (1985). Mount Fuji and Mount Sinai: A critique of Idols, Maryknoll: Orbis Books. 
LaCugna, C. M. (1993). God for Us: The Trinity and Christian Life, San Francisco: Harper San Francisco.

Ma, W. \& Ma, J. (2011). Mission in the Spirit: Toward a Pentecostal/Charismatic Missiology, Oxford: Regnum.

Martinez, J. F., Chan, S., Veli-Matti Kärkkäinen, \& Dyrness, W.A. (2009). The Global Dictionary of Theology, Carol Stream: InterVarsity Press.

McGrath, A. (2011). Christian Theology: An Introduction, Malden: Blackwell Publishers.

Millard, Erickson. (2013). Christian Theology, Grand Rapids: Baker Academics.

Migliore, D. (1991). Faith Seeking Understanding: An Introduction to Christian Theology, Grand Rapids: WB Eerdmans.

Moltmann, J. (2015). The Crucified God, Minneapolis: Fortress Press.

Moltmann, J. (2015). The Living God and the Fullness of Life, Geneva: WCC Publications.

Sanneh L. (1990). "Gospel and Culture: Ramifying the Effects of Scriptural Translation" In Phillip C Stine, Studies in Translation and the Spread of The Church in the past 200 years, Netherlands: Brill.

Sanneh, L. (2009). Translating the Message: The Missionary Impact on Culture, Second Edition, Maryknoll: Orbis Books.

Schnabel, E. (2004). Early Christian Mission: Volume Two, Paul and The Early Church, Downers Grove: IVP Academic.

Smith, T. L. (1978). Religion and Ethnicity in America, The American Historical Review, (Vol. 83, 5), pgs1155-1185.

Stott, J. (1994). The Message of Acts, Bible Speaks Today Series, IVP Academic. Thomas, Norman. ed. 1994. Classical Texts in Mission and World Christianity. Maryknoll: Orbis Books.

Stott, J. (2013). "Living God is a Missionary God". In Ralph D. Winter and Steven C. Hawthorne (Eds.), Perspectives on World Mission Movement: A Reader, Pasadena: William Carey Publishing.

Stroope, M. (2017). Transcending Mission: The Eclipse of a Modern Tradition, Downers Grove: IVP Academic.

Van Engen, C. (2017). Transforming Mission Theology, Pasadena: William Carey Press.

Vanhoozer, K. (1997). "Human Beings: Individual and Social". :In Colin Gunter (ed), Cambridge Companion to Christian Doctrine, , New York: Cambridge University Press.

Volf, M. (1998). After our Likeness: The Church as the Image of the Trinity, WB Eerdmans: Grand Rapids, Michigan. 
Walls, A. F. (2011). "Towards a Theology of Migration" : In Frieder, Ludwig. and Kwabena. Asamoah-Gyadu. (Eds.), African Christian Presence in the West: New Immigrant Congregations and Transnational Networks in North America and Europe. Trenton: Africa World Press.

Walls, A. F. (2002). The Cross-Cultural Process in Christian History: Studies in the Transmission and Appropriation of Faith, Maryknoll, NY: Orbis Books.

Walls, A. F. (1985). Culture and Coherence in Christian History, Scottish Bulletin of Evangelical Theology, (Vol. 3,1),Spring, pgs 1-9.

Wright, C. (2006). The Mission of God: Unlocking the Bible's Grand Narrative, Downers Grove: IVP Academic.

Wright, C. (2010). The Mission of God's People: A Biblical Theology of the Church's Mission, Grand Rapids: Zondervan Academic.

Wu, Jackson. (2015). Rewriting the Gospel for Oral Cultures: Why Honor and Shame Are Essential to the Gospel Story :In Samuel E. Chiang and Grant Lovejoy (Eds). Beyond Literate Western Contexts: Honor \& Shame and Assessment of Orality Preference, Hong Kong: International Orality Network.

Yeh, A. (2016). Polycentric Missiology: Twenty-first Century mission from Everyone to Everywhere, Downers Grove, IL: IVP Academic.

Yong, A. (2014). Renewing Christian Theology: Systematics for a Global Christianity, Waco: Baylor University Press.

Yong, A. (2014). The Missiological Spirit: The Christian Mission Theology in the Third Millennium Global Context, Eugene, OR: Cascade Book.

Yong, A. (2019). Mission after Pentecost: The Witness of the Spirit from Genesis to Revelation, Grand Rapids: Baker Academic.

Zizioulas, J. D. (1985). Being as Communion: Studies in Personhood and the Church, London: Darton, Longman and Todd. 